\title{
Farm-Scale Applicability of Three Covers (Peat, Polystyrene Balls and Synthetic Sheet Roof) to Reduce Ammonia Emissions from Pig Slurry Storage
}

\author{
Laurence Loyon ${ }^{1,2}$, Fabrice Guiziou1,2, Sylvie Picard1,2, Patricia Saint-Cast ${ }^{1,2}$ \\ ${ }^{1}$ National Research Institute of Science and Technology for Environment and Agriculture (IRSTEA), UR OPAALE, \\ Rennes, France \\ ${ }^{2}$ University Bretagne Loire, Rennes, France \\ Email: laurence.loyon@irstea.fr
}

Received 1 April 2016; accepted 24 June 2016; published 27 June 2016

Copyright $(\underset{2016}{ }$ by authors and Scientific Research Publishing Inc.

This work is licensed under the Creative Commons Attribution International License (CC BY). http://creativecommons.org/licenses/by/4.0/

(c) (i) Open Access

\begin{abstract}
Covering the slurry pit has been shown to be one of the best ways to reduce ammonia emissions $\left(\mathrm{NH}_{3}\right)$ during manure management. Yet, few studies have been conducted at farm scale. We studied the feasibility of three cover materials (peat, polystyrene balls and synthetic sheet roof) to reduce ammonia $\left(\mathrm{NH}_{3}\right)$ emissions during on-farm storage of pig slurry. The impact on greenhouse gas emissions, methane $\left(\mathrm{CH}_{4}\right)$, nitrous oxide $\left(\mathrm{N}_{2} \mathrm{O}\right)$ and carbon dioxide $\left(\mathrm{CO}_{2}\right)$ of covering the slurry pit was also evaluated. Simultaneous field experiments were carried out using two similar pits at a farm with peat and polystyrene ball covers, which allowed direct comparison of the feasibility of the two covers to reduce gas emissions (measured using the dynamic chamber technique). Emissions from the third option (using a synthetic sheet roof) were estimated by measuring the concentrations in the headspace under the cover and the air leakage from the cover with a tracer gas $\left(\mathrm{CO}_{2}\right)$. Results showed that the polystyrene balls cover reduced emissions of $\mathrm{NH}_{3}$ during storage by up to $80 \%$ whatever the season, but increased potential greenhouse gas emissions by $20 \%$ in summer. No consistent reduction was achieved with the peat cover even though some individual results seemed to indicate up to $25 \%$ reduction in ammonia emissions; moreover, there was a $30 \%$ increase in $\mathrm{CH}_{4}$ and $\mathrm{CO}_{2}$ emissions during the storage period. The use of a synthetic sheet roof enabled up to $90 \%$ reduction in $\mathrm{NH}_{3}, \mathrm{CH}_{4}$ and $\mathrm{CO}_{2}$ emissions whatever the season.
\end{abstract}

\section{Keywords}

Ammonia, Slurry, Covers, Farm-Scale Measurement, Pig 


\section{Introduction}

Manure management in livestock farming has environmental impacts including air pollution (acidification and aerosols) by ammonia $\left(\mathrm{NH}_{3}\right)$ emissions, and an impact on global warming by nitrous oxide $\left(\mathrm{N}_{2} \mathrm{O}\right)$ and methane $\left(\mathrm{CH}_{4}\right)$ emissions [1] [2].

France is the leading country in the European Union in beef cattle rearing (around 20 million animals) and poultry (300 million), and the third country for pig production (15 million). The resulting solid and liquid manure is mainly collected and stored before being applied to agricultural land. French agriculture accounts for $97 \%$ of national $\mathrm{NH}_{3}$ emissions (679 kt in 2012) of which 76\% comes from the livestock sector [3]. $\mathrm{CH}_{4}$ and $\mathrm{N}_{2} \mathrm{O}$ from livestock represent around 80\% of national emissions (2402 kt of $\mathrm{CH}_{4}$ and $184 \mathrm{kt}$ of $\mathrm{N}_{2} \mathrm{O}$ in 2012). $\mathrm{NH}_{3}$ emission from manure storage has been estimated to range from $9 \%$ to $19 \%$ of total $\mathrm{NH}_{3}$ emissions from pig and cattle farming, respectively [4]. Greenhouse gases $\left(\mathrm{CH}_{4}, \mathrm{~N}_{2} \mathrm{O}\right)$ emitted during manure storage range from $25 \%$ to $54 \%$ of total ammonia emission from pig and cattle farming, respectively [4].

The French government signed several commitments under international conventions (Geneva Convention UNECE/LRTA, Convention on Climate Change UNFCCC) in addition to conforming to European directives (directive 2001/81/EC on National Emission Ceilings and directive 96/61/EC concerning Industrial Emission Directive)aimed at stabilising or reducing national gas emissions,.

Some techniques already exist to reduce $\mathrm{NH}_{3}$ emitted from animal housing and during manure storage and spreading [5] [6]. When slurry is stored outside the building, one of the $\mathrm{NH}_{3}$ reduction techniques is covering the slurry. Different covers have been investigated at pilot-scale, rigid covers, flexible covers, floating covers (peat, straw, oil, plastic film, etc.) and naturally formed crusts [7]-[9]. These covers reduce $\mathrm{NH}_{3}$ emission by reducing the permeability and resistance of the surface to ammonia transfer, or by reducing the size of the emitting surface [10] [11]. A review by Vander Zaag et al. [12] reported a reduction between 50\% and $100 \%$ of $\mathrm{NH}_{3}$ emissions depending on the type of cover. The impact of the cover on GHG emissions is less well documented, and for $\mathrm{CH}_{4}$ emissions, the results obtained using natural floating covers are conflicting. They are reported to have reduced $\mathrm{CH}_{4}$ emission from slurry [13]-[15] mainly by oxidation of $\mathrm{CH}_{4}$ to $\mathrm{CO}_{2}$ [16], whereas other studies using a straw or clay cover reported an increase in $\mathrm{CH}_{4}$ [17]-[19] or no effect [9] [20]. An increase in $\mathrm{N}_{2} \mathrm{O}$ with the use of a natural cover (leca, straw) on slurry has been reported [15] [20] [21]. Although covering is one the main techniques listed in the UNECE guidelines on reducing ammonia emissions [5], little information is available on the effectiveness and feasibility of covers for $\mathrm{NH}_{3}$ reduction under farm operating constraints. Indeed, farm-scale studies are limited because such experiments are labour intensive [8] [22] [23]. In this context, the aim of this study was to conduct a farm-scale evaluation of the feasibility of three covers: (i) a floating peat cover (ii) a raft of polystyrene balls and (iii) a synthetic sheet roof. Our main objective was to assess the reduction in $\mathrm{NH}_{3}$ emissions during the storage of pig slurry. The effect of the covers on the emission of greenhouse gases $\left(\mathrm{CH}_{4}, \mathrm{~N}_{2} \mathrm{O}, \mathrm{CO}_{2}\right)$ during pig slurry storage was also examined.

\section{Material and Methods}

Emissions of $\mathrm{NH}_{3}$ and greenhouse gas $\left(\mathrm{CH}_{4}, \mathrm{~N}_{2} \mathrm{O}, \mathrm{CO}_{2}\right)$ from covered pig slurry were measured at two different pig farms located in Brittany (France).The peat and the polystyrene ball cover experiments were carried out on Farm 1 (F1), and the synthetic sheet roof experiment on Farm 2 (F2). Table 1 summarizes the three experiments carried out with the three covers: experiment 1 (E1) with the peat cover, experiment 2 (E2) with the polystyrene balls cover, and experiment 3 (E3) with the synthetic sheet roof.

\subsection{Assessment of Peat and Polystyrene Ball Covers at Farm F1}

The experiments were carried out at a farrowing-fattening farm (F1) with 200 sows. This farm has two rectangular below-ground concrete pits $(19.5 \mathrm{~m} \times 12 \mathrm{~m}, 3.0 \mathrm{~m}$ deep). The experiment with the peat cover was carried out over a 7-week period in summer 2004. No experiment was conducted in winter as the slurry pits were empty for management reason. The experiment with the polystyrene ball cover was carried out over two 7-week periods, one in autumn 2005 (Period 1) and one in summer 2006 (Period 2).

At the beginning of each experiment, pit 1 and pit 2 were filled with similar slurry. Pit 1 was fitted with a cover (peat cover in experiment E1 and a layer of polystyrene balls in experiment E2) and the second pit (pit 2) was left uncovered as control. After the beginning of experiment, the two pits were frequently refilled with 
Table 1. Summary of the measurement made using the three covers on a pig farm.

\begin{tabular}{|c|c|c|c|c|}
\hline Type of cover & Description & Farm & Experiment & Monitoring period \\
\hline Peat & $\begin{array}{l}\text { Thickness of } 5 \text { - } 15 \mathrm{~cm} \text { of acidic/hydrophilic Baltic peat } \\
1 \text { covered storage pit }+1 \text { uncovered storage pit (control) }\end{array}$ & $\mathrm{F} 1$ & E1 & Summer 2004 \\
\hline Polystyrene ball & $\begin{array}{c}6000 \text { balls }(\varnothing: 20 \mathrm{~cm}) \text { of SPE polystyrene } \\
1 \text { covered store }+1 \text { uncovered store (as control) }\end{array}$ & $\mathrm{F} 1$ & E2 & $\begin{array}{l}\text { Autumn } 2005 \\
\text { Summer } 2006\end{array}$ \\
\hline Synthetic sheet roof & 1 storage pit covered with a synthetic sheet roof & $\mathrm{F} 2$ & E3 & $\begin{array}{l}\text { Winter } 2006 \\
\text { Autumn } 2006\end{array}$ \\
\hline
\end{tabular}

slurry from the pig housing. The volume of slurry stored in the two pits was recorded daily. This arrangement allowed us to evaluate as far as possible the efficiency of the covers in reducing the gas emissions $\left(\mathrm{NH}_{3}, \mathrm{~N}_{2} \mathrm{O}\right.$, $\mathrm{CH}_{4}, \mathrm{CO}_{2}$ ) at the same time scale and in the same weather conditions.

\subsubsection{Description of the Covers}

The peat cover tested in this study was made from an acidic hydrophilic Baltic peat $(\mathrm{pH} 4)$ (according to the commercial data supplied). A minimum peat thickness of $5 \mathrm{~cm}$ was chosen based on the results of [24], who showed that the thickness of the peat influenced the reduction in ammonia emissions. A minimum thickness of $5 \mathrm{~cm}$ implied a $12 \mathrm{~m}^{3}$ volume of peat which was placed on top of the slurry using a straw chopper/blower (Figure 1). The cover made of polystyrene balls cover was applied manually by distributing around 6000 balls (diameter: 20 $\mathrm{cm}$ ) made of SPE polystyrene (density: $23.8 \mathrm{~kg} \cdot \mathrm{m}^{-3}$ ).

\subsubsection{Gas Measurement during Storage $\left(\mathrm{NH}_{3}, \mathrm{CH}_{4}, \mathrm{CO}_{2}\right.$ and $\left.\mathrm{N}_{2} \mathrm{O}\right)$}

Emissions of $\mathrm{NH}_{3}, \mathrm{CH}_{4}, \mathrm{CO}_{2}$ and $\mathrm{N}_{2} \mathrm{O}$ from the covered pit and from the uncovered control pit were determined simultaneously using two dynamic floating chambers [25], one placed on the covered slurry and one placed on the uncovered slurry (control). The device consisted of a floating rectangular polyvinyl chloride (PVC) open bottom chamber placed on the surface of the liquid. In experiment E1 with the peat cover, the surface surrounded by the dynamic chamber was $0.12 \mathrm{~m}^{2}$. In experiment $\mathrm{E} 2$ with the polystyrene ball cover, an area of 0.48 $\mathrm{m}^{2}$ was chosen to surround at least 12 balls. Even if spatial and temporal variability of gaseous emissions was observed and confirmed that reported by other authors [26] [27], we assumed that this variability had the same impact in both pits. The dynamic chambers were left in the same place on the surface of the slurry in both pits throughout the measuring period. However, the chambers were moved slightly at frequent intervals to avoid the formation of a natural crust below the chamber, especially in the pit containing the control slurry.

During the measurement period, gas emitted by the covered slurry and the control slurry surrounding the dynamic chambers was removed from the chambers by pumping in clean air with an appropriate set of pumps, flow meters, volumetric air metres, and Teflon sampling tubes. The air flow through the dynamic chamber was set at $30 \mathrm{~L} \cdot \mathrm{min}^{-1}$. The velocity of the flow of air over the slurry surface was between 0.05 and $0.1 \mathrm{~m} \cdot \mathrm{s}^{-1}$. Inlet and outlet air passed through two air sampling lines to a mobile laboratory where the air was analysed using an appropriate technique. The concentrations of gaseous emissions were measured continuously throughout the experiment.

The concentration of ammonia was measured either using the acid trap method or by infrared absorption spectrometry using a gas analyser (Innova 1312, Air Tech Instruments). The acid trap method consists in continuously passing the sampled air through acid traps (0.5N sulphuric acid) at an airflow of $5 \mathrm{~L} \cdot \mathrm{min}^{-1}$ [10] [28] followed by alkaline distillation and titration of the final acid ammonia solution. For $\mathrm{NH}_{3}$ measurement by infrared absorption spectrometry, the detection limit of the Innova 2012 was $0.2 \mathrm{ppm}$ for $\mathrm{NH}_{3}, 0.4 \mathrm{ppm}$ for $\mathrm{CH}_{4}$, $2.5 \mathrm{ppm}$ for $\mathrm{CO}_{2}$ and $0.03 \mathrm{ppm}$ for $\mathrm{N}_{2} \mathrm{O} . \mathrm{CH}_{4}$ and $\mathrm{CO}_{2}$ concentrations were determined by infrared detection (URAS 10, 14 and Innova 1312). $\mathrm{N}_{2} \mathrm{O}$ concentrations were determined during monitoring with an Innova 1312. Laboratory comparisons (results not reported in this paper) showed (i) that whether determined by acid trap or by infrared detection (Innova 1312), the concentration of ammonia and (ii) the concentration of methane measured by infrared (URAS 10, 14 and Innova 1312) were in the same order of magnitude whatever the method used.

\subsubsection{Assessment of the Efficiency of the Covers}

The efficiency of the peat cover and the polystyrene ball cover in reducing emissions of $\mathrm{NH}_{3}$ and of the three 


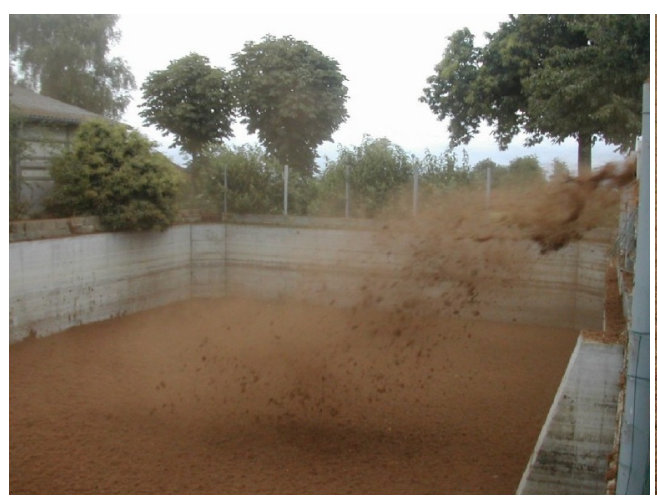

(a)

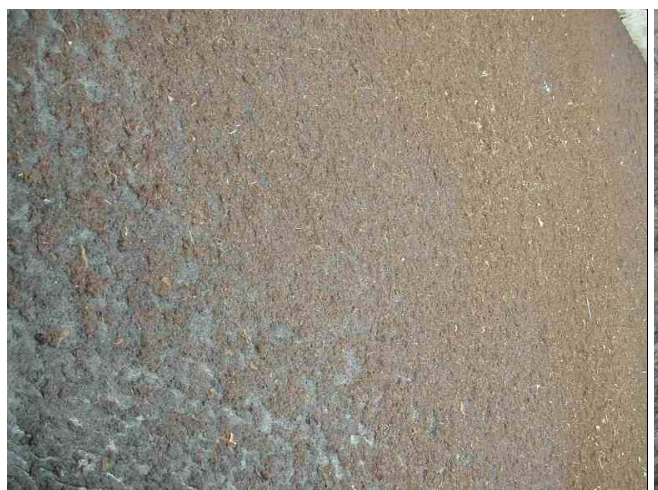

(c)

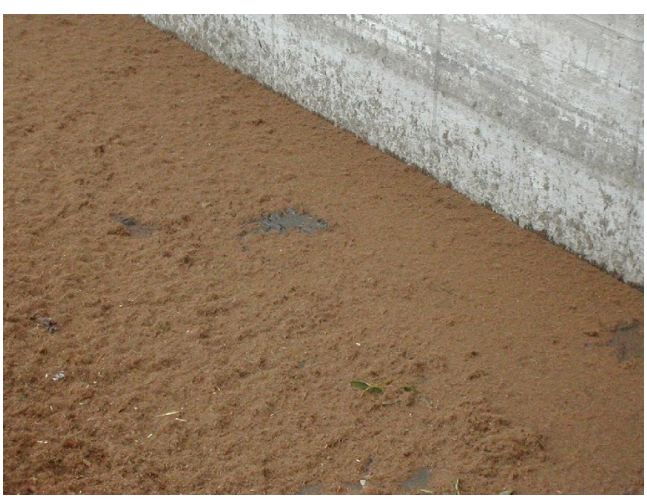

(b)

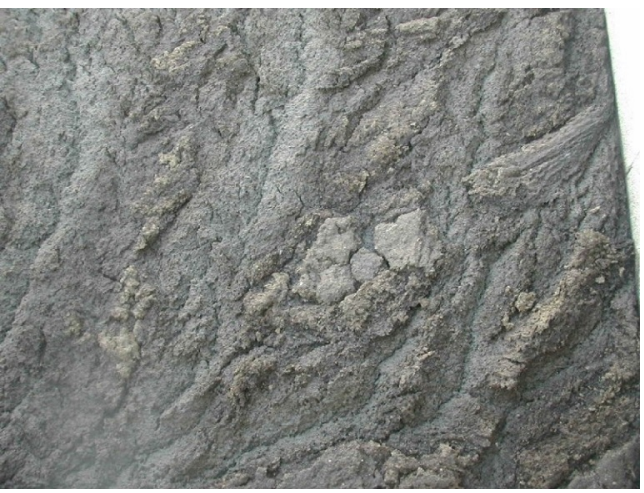

(d)

Figure 1. Changes in the peat cover over the period of the experiment. Photo (a) -application; photo (b) - 1 day later; photo (c) — after 4 days; photo d after 40 days.

greenhouse gases $\left(\mathrm{CH}_{4}, \mathrm{~N}_{2} \mathrm{O}, \mathrm{CO}_{2}\right)$ was assessed by comparing the emission factor $\left(\mathrm{EF}_{\text {gas }}\right)$ of the covered slurry (peat or balls) in pit 1 with the control slurry in pit 2. The emission factors are expressed as $g\left[\mathrm{NH}_{3}-\mathrm{N}\right] \mathrm{m}^{-2} \cdot \mathrm{d}^{-1}$, $\mathrm{g}\left[\mathrm{N}_{2} \mathrm{O}-\mathrm{N}\right] \mathrm{m}^{-3} \cdot \mathrm{d}^{-1}, \mathrm{~g}\left[\mathrm{CH}_{4}-\mathrm{C}\right] \mathrm{m}^{-3} \cdot \mathrm{d}^{-1}$ and $\mathrm{g}\left[\mathrm{CO}_{2}-\mathrm{C}\right] \mathrm{m}^{-3} \cdot \mathrm{d}^{-1}$, respectively.

\subsection{Assessment of a Synthetic Sheet Roof at Farm 2}

The experiments with the synthetic sheet roof were carried out at a second pig farm (F2) with 133 sows in winter and summer 2006.

\section{Slurry Storage and Manure Management}

The farmer used to store the slurry from the different pig housings in a $1000 \mathrm{~m}^{3}$ concrete circular pit (surface area $166 \mathrm{~m}^{2}$ ). This pit was covered by a synthetic sheet roof suspended $1 \mathrm{~m}$ above the pit by a central mast. This configuration resulted in a cone-shape headspace with an estimated volume of $55.3 \mathrm{~m}^{3}$.

As the pit was not hermetically sealed by the synthetic sheet roof, gaseous emissions were determined by measuring the concentrations in the headspace under the cover and the air leakage with a tracer gas $\left(\mathrm{CO}_{2}\right)$ as described in previous studies [29]-[31]. Air leakage from the covered pit expressed in cubic meters per day $\left(\mathrm{m}^{3} \cdot \mathrm{d}^{-1}\right)$ was estimated by injecting a known quantity of $\mathrm{CO}_{2}$ and by measuring the reduction in concentration over time. Air leakage was measured according to first order kinetics as described by Tingey et al. (2000) [32]:

$$
\frac{\mathrm{dC}_{\mathrm{CO}_{2}}}{\mathrm{~d} t}=\mathrm{LC}_{\mathrm{CO}_{2}}
$$

where $\mathrm{L}$ is the leakage decay constant (time $\left.{ }^{-1}\right) ; \mathrm{C}_{\mathrm{CO}_{2}}$ is the concentration of $\mathrm{CO}_{2}(\mathrm{ppmv})$, and $\mathrm{t}$ is time. Carbon dioxide emissions during storage over the measurement period were relatively low compared to the quantity of $\mathrm{CO}_{2}$ injected. The leakage decay constant (equivalent to the number of headspace volumes per unit time) was 
determined by integration to give a classic form $\log \left(\mathrm{C}_{\mathrm{t}}\right)=\mathrm{L} * \mathrm{t}+\log \left(\mathrm{C}_{0}\right)$, so plotting the log of concentration versus time gives a line of slope $\mathrm{L}$. The emission factor (EF, expressed in g[C or N] d $\mathrm{d}^{-1}$ ) of $\mathrm{NH}_{3}, \mathrm{CH}_{4}, \mathrm{~N}_{2} \mathrm{O}$ and $\mathrm{CO}_{2}$ were calculated using the following relation:

$$
\mathrm{EF}_{\mathrm{gas}_{\mathrm{i}}}=\mathrm{L}^{*} \mathrm{~V}_{\mathrm{air}} * \mathrm{C}_{\mathrm{gas}_{\mathrm{i}}}
$$

where $\mathrm{L}$ is the leakage decay constant $\left(\mathrm{d}^{-1}\right)$; $\mathrm{V}_{\text {air }}$ is the volume of air under the cover $\left(\mathrm{m}_{\text {air }}^{3}\right)$; $\mathrm{C}_{\text {gas }_{\mathrm{i}}}$ is the concentration ( $\mathrm{gm}_{\text {air }}^{-3}$ ) of $\mathrm{NH}_{3}, \mathrm{~N}_{2} \mathrm{O}, \mathrm{CH}_{4}$ or $\mathrm{CO}_{2}$

$\mathrm{NH}_{3}, \mathrm{CH}_{4}, \mathrm{CO}_{2}$ and $\mathrm{N}_{2} \mathrm{O}$ concentrations in the pit headspace were monitored by continuously sampling air at the perimeter of the pit where, according to [33], air leakage was assumed to occur. However, gaseous emissions were also measured intermittently using an enclosed chamber sealed onto the cover itself to check air leakage did not occur through the cover. In winter, $\mathrm{CH}_{4}, \mathrm{CO}_{2}$ and $\mathrm{NO}_{2}$ concentrations were measured on site by infrared detection (Uras 10,14) and the concentration of $\mathrm{NH}_{3}$ was determined by trapping the drawn up air in acid solution $\left(\mathrm{H}_{2} \mathrm{SO}_{4}, 0.5 \mathrm{~N}\right)$. In summer, concentrations of the gases were measured by infrared absorption spectrometry (Innova 1312).

\section{Results}

The characteristics of the pig slurry are listed in Table 2 and are given as information but were not used to calculate $\mathrm{NH}_{3}$ emissions in relation to the $\mathrm{N}$ mass balance. Mean gaseous emissions in the experiments with the peat cover, the polystyrene ball cover and the synthetic sheet roof are summarized in Table 3. Daily mean emissions of $\mathrm{NH}_{3}, \mathrm{CH}_{4}$ and $\mathrm{CO}_{2}$ expressed as $\mathrm{g}\left[\mathrm{NH}_{3}-\mathrm{N}\right] \mathrm{m}^{-2} \cdot \mathrm{d}^{-1}, \mathrm{~g}\left[\mathrm{~N}_{2} \mathrm{O}-\mathrm{N}\right] \mathrm{m}^{-3} \cdot \mathrm{d}^{-1}, \mathrm{~g}\left[\mathrm{CH}_{4}-\mathrm{C}\right] \mathrm{m}^{-3} \cdot \mathrm{d}^{-1}$ and $\left.\mathrm{g}_{\mathrm{CO}}-\mathrm{C}\right]$ $\mathrm{m}^{-3} \cdot \mathrm{d}^{-1}$, respectively, varied over time as indicated by the standard deviation, given in brackets (Table 2). In all the experiments, nitrous oxide emissions were below the detection limit of the dynamic chamber $(0.03 \mathrm{ppm})$.

Table 2. Characteristics of the pig slurry stored under the synthetic sheet and in the other pits before the peat and polystyrene ball covers were put in place.

\begin{tabular}{ccccc}
\hline & $\begin{array}{c}\text { Experiment with Peat cover } \\
\text { (slurry sampled in summer) }\end{array}$ & $\begin{array}{c}\text { Experiment with polystyrene balls } \\
\text { (slurry sampled in autumn) }\end{array}$ & \multicolumn{2}{c}{ Slurry covered with synthetic sheet } \\
\hline & & & Winter & Summer \\
\hline $\mathrm{TAN}\left(\mathrm{gN} \cdot \mathrm{kg}^{-1}\right)$ & 2.3 & 3.3 & 2.2 & 2.4 \\
$\mathrm{TKN}\left(\mathrm{gN}^{-1} \mathrm{~kg}^{-1}\right)$ & 3.8 & 4.9 & 2.4 & 4.7 \\
$\mathrm{DM}\left(\mathrm{g}^{-1} \mathrm{~kg}^{-1}\right)$ & 53 & 66 & 77 & 71 \\
$\mathrm{OM}\left(\mathrm{g} \cdot \mathrm{kg}^{-1}\right)$ & 38 & 49 & 29 & 51 \\
$\mathrm{pH}$ & 7.6 & 7.9 & 8.2 & 7.6 \\
\hline
\end{tabular}

*Sampling was not possible in summer due to the small volume of stored slurry.

Table 3. Mean gaseous emissions from the uncovered and covered pig slurry storage pits. Values in parentheses are standard deviations.

\begin{tabular}{|c|c|c|c|c|c|c|}
\hline & & & $\begin{array}{c}\mathrm{NH}_{3} \\
\left(\mathrm{~g}[\mathrm{~N}] \mathrm{m}^{-2} \cdot \mathrm{d}^{-1}\right)\end{array}$ & $\begin{array}{c}\mathrm{N}_{2} \mathrm{O} \\
\left(\mathrm{g}[\mathrm{N}] \mathrm{m}^{-3} \cdot \mathrm{d}^{-1}\right)\end{array}$ & $\begin{array}{c}\mathrm{CH}_{4} \\
\left(\mathrm{~g}[\mathrm{C}] \mathrm{m}^{-3} \cdot \mathrm{d}^{-1}\right)\end{array}$ & $\begin{array}{c}\mathrm{CO}_{2} \\
\left(\mathrm{~g}[\mathrm{C}] \mathrm{m}^{-3} \cdot \mathrm{d}^{-1}\right)\end{array}$ \\
\hline \multirow{2}{*}{ Peat cover } & Control & & $4.1(3.9)$ & \multirow{2}{*}{ ND } & 56.9 (9.9) & 44.5 (6.9) \\
\hline & & Summer & $3.1(3.1)$ & & $75.8(62.4)$ & $58.5(48.6)$ \\
\hline \multirow{4}{*}{ Polystyrene balls } & \multirow{2}{*}{ Control } & Autumn & $0.6(0.9)$ & \multirow{2}{*}{ ND } & $67.8(32.4)$ & 34.9 (18.7) \\
\hline & & Summer & $3.5(1.1)$ & & $90.2(30.7)$ & 239 (106.5) \\
\hline & \multirow{2}{*}{ Covered } & Autumn & $0.5(82.1)$ & \multirow{2}{*}{ ND } & $65.8(50.3)$ & 34.3 (26.7) \\
\hline & & Summer & $0.8(0.4)$ & & $139.3(51.3)$ & $116.6(35.6)$ \\
\hline \multirow{2}{*}{ Synthetic sheet } & \multirow{2}{*}{ Covered } & Winter & $0.013(2.7)$ & \multirow{2}{*}{ ND } & $0.3(0.1)$ & $0.2(0.1)$ \\
\hline & & Summer & $0.006(3.0)$ & & $1.7(0.3)$ & $4.7(1.0)$ \\
\hline
\end{tabular}




\subsection{Assessment of the Peat Cover (Experiment E1 at Farm 1)}

Due to lack of space between the storage pits and the housings, the peat could only be spread over the slurry surface from a single point resulting in a variation in thickness estimated at between 5 and $15 \mathrm{~cm}$ (visual observation). Depending on the climate conditions (not monitored) the peat cover varied in moisture content over the period of experiment (Figure 1). At the start of the experiment, the peat was dry but was moistened through contact with the slurry. Over time, the peat resembled a crust with irregular cracks.

Daily mean ammonia emissions varied over the measurement period in summer. Ammonia emissions from the control slurry varied between 1.4 to $18.2 \mathrm{~g}\left[\mathrm{NH}_{3}-\mathrm{N}\right] \mathrm{m}^{-2} \cdot \mathrm{d}^{-1}$ with a mean emission factor of $\left.4.1 \mathrm{~g}^{-2} \mathrm{NH}_{3}-\mathrm{N}\right]$ $\mathrm{m}^{-2} \cdot \mathrm{d}^{-1}$ over the measurement period. Ammonia emissions from the peat covered slurry varied between zero $(<0.001)$ (the day the slurry was covered) and $8.7 \mathrm{~g}\left[\mathrm{NH}_{3}-\mathrm{N}\right] \mathrm{m}^{-2} \cdot \mathrm{d}^{-1}$. The mean emission factor over the measurement period was $3.1 \mathrm{~g}\left[\mathrm{NH}_{3}-\mathrm{N}\right] \mathrm{m}^{-2} \cdot \mathrm{d}^{-1}$. The level of emission of carbon gases $\left(\mathrm{CH}_{4}\right.$ and $\left.\mathrm{CO}_{2}\right)$ was $101 \mathrm{~g}[\mathrm{C}]$ $\mathrm{m}^{-3} \cdot \mathrm{d}^{-1}$ (with $56.1 \%$ as $\mathrm{CH}_{4}$ ) from the uncovered pit and $134 \mathrm{~g}[\mathrm{C}] \mathrm{m}^{-3} \cdot \mathrm{d}^{-1}$ (with $56.4 \%$ as $\mathrm{CH}_{4}$ ) from the peat covered pit. Based on these mean emission factors, the peat cover reduced ammonia emissions by $24.4 \%$ but increased carbon emissions by 32\%. However, the difference in ammonia and carbon emissions over the measurement period was not statistically significant (Wilcoxon rank sum test). The effect of the peat cover on ammonia and carbon emission was irregular. Sometimes the covered slurry emitted more ammonia or less carbon than the uncovered slurry. These results are probably linked with changes in the peat cover due to climatic conditions.

\subsection{Assessment of the Polystyrene Ball Cover (Experiment E2 at Farm 1)}

The balls were thrown into the pit 1 by hand by four people at the same time as the slurry was being mixed with a brewer. Mixing created a circular movement which dispersed the balls towards the surface of the slurry. The process lasted 30 minutes. At the end, the balls covered the whole surface of the stored slurry (Figure 2). In

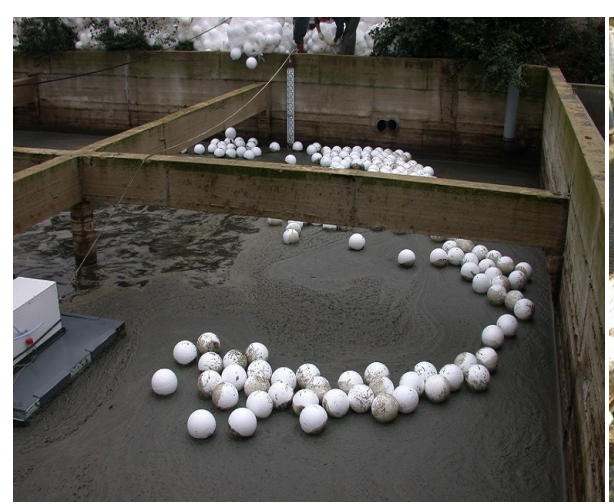

(a)

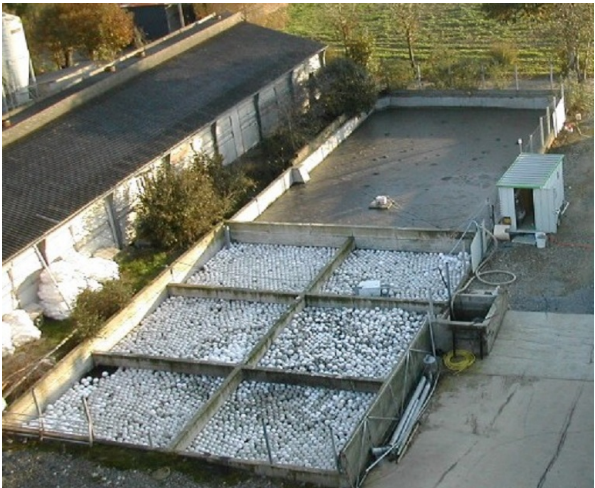

(b)

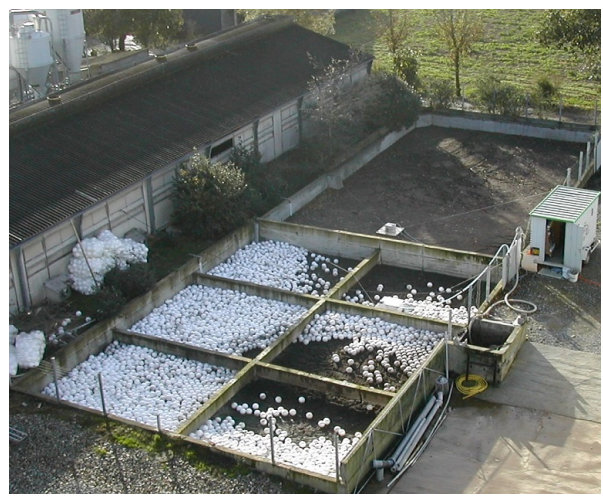

(c)

Figure 2. Changes in the polystyrene ball cover over the period of the experiment: (a) balls being thrown onto the slurry, (b) final cover before monitoring began and (c) the cover 2 weeks later. 
exposed areas of the slurry pit, high winds blew the polystyrene balls away just after the start of the autumn experiment (Figure 2). A second layer of balls was applied in these exposed areas to protect them. This succeeded because no uncovered area was observed in summer. Many of the polystyrene balls were damaged when the farmer stirred the slurry before applying it to the fields, but the damage did not affect the surface cover by the balls.

Like in the experiment with the peat cover, ammonia and carbon emissions varied over the measurement period and also between seasons. Mean ammonia emissions from the covered slurry over the measurement periods were 0.1 and $1.4 \mathrm{~g}[\mathrm{NH} 3-\mathrm{N}] \mathrm{m}^{-2} \cdot \mathrm{d}^{-1}$, in autumn and in summer, respectively. In the control experiment, mean

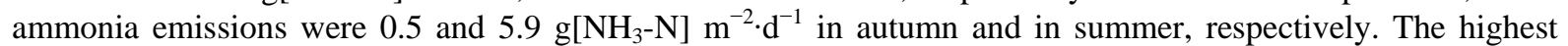
ammonia emissions were measured in summer in both pits. The lowest value, $\left(0.5 \mathrm{~g}\left[\mathrm{NH}_{3}-\mathrm{N}\right] \mathrm{m}^{-2} \cdot \mathrm{d}^{-1}\right)$, measured in autumn in the control slurry, corresponded to the development of a crust over the slurry, which reduced ammonia emissions. When the crust was broken when the slurry was stirred, ammonia emissions increased again until a new crust formed. Based on these results, a cover made of polystyrene balls could reduce ammonia emissions during storage by up to $80 \%$ whatever the season.

The cover made of balls did not significantly affect carbon emissions in autumn when the control slurry emitted $101 \mathrm{~g}[\mathrm{C}] \mathrm{m}^{-3} \cdot \mathrm{d}^{-1}$ while the covered slurry emitted $105 \mathrm{~g}[\mathrm{C}] \mathrm{m}^{-3} \cdot \mathrm{d}^{-1}$. In summer, carbon emissions from the control slurry were significantly higher than from the covered slurry, $329 \mathrm{~g}[\mathrm{C}] \mathrm{m}^{-3} \cdot \mathrm{d}^{-1}$ and $255 \mathrm{~g}[\mathrm{C}] \mathrm{m}^{-3} \cdot \mathrm{d}^{-1}$, respectively. The ball cover reduced overall carbon emission by $24 \%$. However, the cover also modified the $\mathrm{CH}_{4} / \mathrm{CO}_{2}$ ratio of the biogas produced by the slurry. The covered slurry emitted more $\mathrm{CH}_{4}$ while the control slurry emitted more $\mathrm{CO}_{2}$. In this way, if we consider the GWP of $\mathrm{CH}_{4}\left(\mathrm{CH}_{4}: 21\right.$ eq- $\left.\mathrm{CO}_{2}\right)$, the polystyrene ball cover increased the global warming potential (GWP) of the slurry by $23 \%$.

\subsection{Assessment of the Synthetic Sheet Roof (Experiment E3 at Farm 2)}

No gas emissions through the synthetic sheet roof were measured by the enclosed chamber sealed on the cover. This result confirmed that gas emissions only occurred at the perimeter of the roof by air leakage. The tracer gas technique by $\mathrm{CO}_{2}$ injection and the monitoring of the $\mathrm{CO}_{2}$ decrease in the headspace under the cover gave a value for the rate of air leakage: with no wind, the air leakage rate was $66.6 \mathrm{~m}^{3} \cdot \mathrm{d}^{-1}$ in winter and $48.6 \mathrm{~m}^{3} \cdot \mathrm{d}^{-1}$ in summer. According to the gas concentration monitored in the storage headspace and the air leakage rate, the mean ammonia and carbon emissions were evaluated at 6 to $13 \mathrm{mg}\left[\mathrm{NH}_{3}-\mathrm{N}\right] \mathrm{m}^{-2} \cdot \mathrm{d}^{-1}$ and at 0.5 to $9.2 \mathrm{~g}[\mathrm{C}]$ $\mathrm{m}^{-3} \cdot \mathrm{d}^{-1}$.

\section{Discussion}

In all the experiments, ammonia emissions varied over the storage period. Many studies have shown that ammonia emissions are affected by both weather conditions and by the characteristics of the slurry [34]. When monitored, nitrous oxide emissions were under the detection limit of the gas analyser. This result was expected because, when slurry is stored in anaerobic conditions, the level of partial oxidation of ammonia is very low or nearly zero [35] [36].

$\mathrm{NH}_{3}$ emissions from the control slurry in the peat cover experiment $\left(4.1 \mathrm{~g}\left[\mathrm{NH}_{3}-\mathrm{N}\right] \mathrm{m}^{-2} \cdot \mathrm{d}^{-1}\right)$ and in the polystyrene ball experiment $\left(3.5 \mathrm{~g}\left[\mathrm{NH}_{3}-\mathrm{N}\right] \mathrm{m}^{-2} \cdot \mathrm{d}^{-1}\right)$ are both in accordance with results of previous studies. Emissions of ammonia from stored pig slurry have been reported to range from 1.8 to $12 \mathrm{~g}\left[\mathrm{NH}_{3}-\mathrm{N}\right] \mathrm{m}^{-2} \cdot \mathrm{d}^{-1}$. Whatever the experiment, the highest emissions were measured in summer because both ammonia volatilisation and organic matter decomposition are increased by higher temperatures. However, comparing our results with those of other studies is not easy as different techniques are often used to measure gas emissions from stored slurry. As noted by [27] a wide range of emissions can be found in the literature depending on the measuring technique used.

The reduction of ammonia by peat (24\%) observed at the farm scale in our study is rather low compared with the results obtained by [10], who reported a $100 \%$ reduction in ammonia emissions in a laboratory experiment with a peat cover. This difference in results could be due to the damage caused to the peat cover during the farm experiment compared to no damage in the laboratory experiment. Moreover, as pointed out by [37], laboratory studies are usually conducted with limited volumes and depths of slurry, which may cause differences in the gas generation and emission processes. In our study the higher carbon emissions from the peat cover on some occasions could be the result of the reactive organic matter content of peat which can decompose when wet. 
The reduction of ammonia emission from $3.5 \mathrm{~g}\left[\mathrm{NH}_{3}-\mathrm{N}\right] \mathrm{m}^{-2} \cdot \mathrm{d}^{-1}$ to $0.5 \mathrm{~g}\left[\mathrm{NH}_{3}-\mathrm{N}\right] \mathrm{m}^{-2} \cdot \mathrm{d}^{-1}$ with a cover made of polystyrene balls is in the same order of magnitude as the value reported by [38] with other covers (natural crust, straw, leca, etc.).

Emissions from slurry covered with a synthetic sheet roof were low compared to those reported in previous studies, even when the incertitude due to the gas tracer technique is taken into account. Our results are close to those obtained by [31] who reported ammonia emissions from covered cattle slurry ranging from 18 to 335 $\mathrm{mg}\left[\mathrm{NH}_{3}-\mathrm{N}\right] \mathrm{m}^{-2} \cdot \mathrm{d}^{-1}$ in winter. [22] reported a reduction of nearly $100 \%$ in ammonia emissions when the slurry was covered with a synthetic sheet roof.

The reduction in ammonia emissions obtained by covering the slurry during storage mainly occurs by affecting the $\mathrm{NH}_{3}$ transfer from the slurry surface to the atmosphere and/or by reducing the emitting area [11] [38] [39]. Moreover, the peat cover has the additional property of adsorbing and/or absorbing ammonia, which could affect the ammonia emissions measured [10] [40].

The impact of the physical barrier on carbon emissions varied with the nature of the cover. Peat covers reduced or increased carbon emission depending on whether it was wet or dry, probably due to decomposition of its carbon content, like oxidation of $\mathrm{CH}_{4}$ in the peat crust [16]. A cover made of polystyrene balls appears to modify the biogas emitted by covered slurry by increasing the percentage of methane. The low carbon emissions obtained with a synthetic sheet roof are in agreement with results obtained in other studies [31] [41] and could be due to the inhibition of the methanogenic processes by the free ammonia content of slurry which is retained in the slurry due to the cover.

Because the use of peat covers will require screening before injection spreading and as no statistical effect on our experimental data was observed, peat covers can be considered as an unsatisfactory way of reducing ammonia emissions. However, a layer of balls or a synthetic sheet roof can be considered as effective in reducing ammonia emissions. To be effective over a long period, the raft of polystyrene balls need to shaped optimally to avoid dispersal by the wind or destruction when the slurry is stirred. Its elimination or reuse also needs to be taken into account, although the problem of elimination could be overcome by using a cover made of biodegradable matter.

Our results are an indication of the effectiveness of covers in reducing ammonia emission at farm scale. Undeniably, the techniques used to measure gas emissions (dynamic chamber and gas tracer) are all subject to discussion. The dynamic chamber disturbed environmental conditions (wind speed, rainfall, temperature, etc.) and gas emissions by covering a part of the surface of the slurry. Nevertheless, the use of this technique to compare different storage or slurry treatments is considered acceptable. Measuring air leakage from the pit covered by the synthetic sheet roof using tracer gas may also be subject to error.

\section{Conclusions}

Of the three covers tested at the farm scale, the peat cover had no significant effect on ammonia emissions during storage. Indeed, at some periods, ammonia and carbon emissions from peat covered slurry were higher than those from the control slurry due to damage caused to the peat surface. A cover made of polystyrene balls or a synthetic sheet roof reduced ammonia emissions by more than $80 \%$ during storage. A cover made of balls could be a very effective way to reduce ammonia emissions during storage but other materials need to be tested to make the procedure more sustainable.

The results of this work underline the need to scale up research from the laboratory to the farm to account for the impact of the dimensions of the pit, wind, solar radiation, rain, etc., on the effectiveness of any technique in reducing ammonia emissions. But at the same time, this study underlines the need to assess different types of covers at both farm and the laboratory scale to understand and enhance the processes involved.

\section{Acknowledgements}

This study was funded by the French Environment and Energy Management Agency (ADEME), the Ministry of Agriculture and Fishery and the Regional Council of Brittany. The authors would like to thank all the livestock farmers involved in the study for their cooperation and technical assistance.

\section{References}

[1] Steinfeld, H., Gerber, P., Wassenaar, T., Castel, V., Rosales, M. and de Haan, C. (2006) Livestock’s Long Shadow- 
Environmental Issues and Options. FAO, Rome.

[2] Chadwick, D., Sommer, S., Thorman, R., Fangueiro, D., Cardenas, L., Amon, B. and Misselbrook, T. (2011) Manure Management: Implications for Greenhouse Gas Emissions. Animal Feed Science and Technology, 166-167, 514-531. http://dx.doi.org/10.1016/j.anifeedsci.2011.04.036

[3] Citepa (2014) Inventaire des émissions de polluants atmosphériques en France au titre de la convention sur la pollution atmosphérique transfrontalière à longue distance et de la directive Européenne relative aux plafonds d'émissions nationaux (NEC). CEE-NU/NFR \& NEC. Mars 2014, 294 p.

[4] Gac, A., Beline, F., Bioteau, T. and Maguet, K. (2007) A French Inventory of Gaseous Emissions $\left(\mathrm{CH}_{4}, \mathrm{~N}_{2} \mathrm{O}, \mathrm{NH}_{3}\right)$ from Livestock Manure Management Using a Mass-Flow Approach. Livestock Science, 112, 252-260. http://dx.doi.org/10.1016/j.livsci.2007.09.006

[5] UNECE (2014) Guidance Document on Preventing and Abating Ammonia Emissions from Agricultural. ECE/EB. AIR/120. 7 February 2014, UNECE, Geneva, 100 p.

[6] Loyon, L., Burton, C.H., Misselbrook, T., Webb, J., Philippe, F.X., Aguilar, M., Doreau, M., Hassouna, M., Veldkamp, T., Dourmad, J.Y., Bonmati, A., Grimm, E. and Sommer, S.G. (2016) Best Available Technology for European Livestock Farms: Availability, Effectiveness and Uptake. Journal of Environmental Management, 166, 1-11. http://dx.doi.org/10.1016/j.jenvman.2015.09.046

[7] Rodhe, L., Ascue, J. and Nordberg, Å. (2010) Greenhouse Gas Emissions from Stored Slurry with and without Different Covers. Proceedings of the 14th Ramiran Conference, Lisboa, 13-15 September 2010, 4 p.

[8] Balsari, P., Dinuccio, E. and Gioelli, F. (2013) A Floating Coverage System for Digestate Liquid Fraction Storage. Bioresource Technology, 134, 285-289. http://dx.doi.org/10.1016/j.biortech.2013.02.021

[9] Misselbrook, T., Perazzolo, F. and Hunt, J. (2015) Gaseous Emissions from Slurry Storage-Influence of Temperature and Potential Mitigation Methods. Proceedings of RAMIRAN 2015-16th International Conference Rural-Urban Symbiosis. Abstract book 8-10 September 2015 Hamburg University of Technology, Germany, 4 p.

[10] Portejoie, S., Martinez, J., Guiziou, F. and Coste, C.M. (2003) Effect of Covering Pig Slurry Stores on the Ammonia Emission Processes. Bioresource Technology, 87, 199-207. http://dx.doi.org/10.1016/S0960-8524(02)00260-2

[11] Miner , J.R., Humenik, F.J., Rice, J.M., Rashash, D.M.C., Williams, C.M., Robarge, W., Harris, D.B. and Sheffield, R. (2003) Evaluation of a Permeable, $5 \mathrm{~cm}$ Thick, Polyethylene Foam Lagoon Cover. Transactions of the ASAE, 46, 1421-1426. http://dx.doi.org/10.13031/2013.15442

[12] Vander Zaag, A.C., Gordon, R.J., Glass, V.M. and Jamieson, R.C. (2008) Floating Covers to Reduce Gas Emissions from Liquid Manure Storages: A Review. Applied Engineering in Agriculture, ASABE, 24, 657-671.

[13] Hilhorst, M.A., Willers, H.C., Groenestein, C.M. and Monteny, G.J. (2001) Effective Strategies to Reduce Methane Emissions from Livestock. ASAE Annual International Meeting, Sacramento Convention Center, Sacramento, 30 July1 August.

[14] Sommer, S.G., Petersen, S.O. and Sogaard, H.T. (2000) Greenhouse Gas Emission from Stored Livestock Slurry. Journal of Environmental Quality, 29, 744-751. http://dx.doi.org/10.2134/jeq2000.00472425002900030009x

[15] Dinuccio, E., Balsari, P. and Gioelli, F. (2015) Reduction of Gaseous Emission from Pig Slurry Storage Tanks by Different Covering Materials. Proceedings of RAMIRAN 2015-16th International Conference Rural-Urban Symbiosis. Abstract book 8-10 September 2015, Hamburg University of Technology, Germany, 4 p.

[16] Petersen, S.O., Amon, B. and Gattinger, A. (2005) Methane Oxidation in Slurry Storage Surface Crusts. Journal of Environmental Quality, 34, 455-461.

[17] Hüther, L., Schuchardt, F. and Wilcke, T. (1997) Emissions of Ammonia and Greenhouse Gases during Storage and Composting of Animal Manures. Proceedings of International Symposium "Ammonia and Odour Control from Animal Production Facilities", Vinkeloord, 6-10 October 1997, 327-334.

[18] Pahl, O., Williams, A.G. and Sneath, R.W. (2002) Reduction of Ammonia and Odour Emissions from Pig Slurry under Slats Using Oil and Foam Layers. Environmental Technology, 23, 395-403. http://dx.doi.org/10.1080/09593332508618404

[19] Cicek, N., Zhou, X.J., Zhang, Q. and Tenuta, M. (2004) Determination of the Impact of Straw Cover on Greenhouse Gas and Odor Emissions from Manure Storage Lagoons Using a Flux Hood. 2004 ASAE/CSAE Annual International Meeting, the Westin, Government Centre, Ottawa, Paper Number: 044054, 9 p.

[20] Rodhe, L., Abubaker, J., Ascue, J., Pell, M. and Nordberg, Å. (2012) Greenhouse Gas Emissions from Pig Slurry during Storage and after Field Application in Northern European Conditions. Biosystems Engineering, 113, 379-394. http://dx.doi.org/10.1016/j.biosystemseng.2012.09.010

[21] Amon, B., Kryvoruchko, V. and Amon, T. (2006) Influence of Different Methods of Covering Slurry Stores on Greenhouse Gas and Ammonia Emissions. International Congress Series, 1293, 315-318.

http://dx.doi.org/10.1016/j.ics.2006.03.001 
[22] Scotford, I.M. and Williams, A.G. (2001) Practicalities, Costs and Effectiveness of a Floating Plastic Cover to Reduce Ammonia Emissions from a Pig Slurry Lagoon. Journal of Agricultural Engineering Research, 80, 273-281. http://dx.doi.org/10.1006/jaer.2001.0744

[23] Viguria, M., Sanz-Cobeña, A., López, D.M., Arriaga, H. and Merino, P. (2015) Ammonia and Greenhouse Gases Emission from Impermeable Covered Storage and Land Application of Cattle Slurry to Bare Soil. Agriculture, Ecosystems \& Environment, 199, 261-271. http://dx.doi.org/10.1016/j.agee.2014.09.016

[24] Portejoie, S. (2002) Volatilisation ammoniacale lors du stockage et à l'épandage de lisiers de porc: Impact des apports protéiques, de l'utilisation de couvertures de fosse et d'additifs. Thèse de Doctorat de L’Université de Perpignan, 137 p.

[25] Peu, P., Beline, F. and Martinez, J. (1999) A Floating Chamber for estimating Nitrous Oxide Emissions from Farm Scale Treatment Units for Livestock Wastes. Journal of Agricultural Engineering Research, 73, 101-104. http://dx.doi.org/10.1006/jaer.1998.0399

[26] Espagnol, S., Loyon, L., Guiziou, F., Robin, P., Bossuet, I. and Hassouna, M. (2008) Measuring Gaseous Emissions from Stored Pig Slurry. The 8th International Livestock Symposium, Iles VIII, Iguassu Falls, 31 August-4 September 2008, 207-214.

[27] Balsari, P., Airoldi, G., Dinuccio, E. and Gioelli, F. (2007) Ammonia Emissions from Farmyard Manure Heaps and Slurry Stores-Effect of Environmental Conditions and Measuring Methods. Biosystems Engineering, 97, 456-463. http://dx.doi.org/10.1016/j.biosystemseng.2007.03.033

[28] Jarret, G., Cerisuelo, A., Peu, P., Martinez, J. and Dourmad, J.-Y. (2012) Impact of Pig Diets with Different Fibre Contents on the Composition of Excreta and Their Gaseous Emissions and Anaerobic Digestion. Agriculture, Ecosystems \& Environment, 160, 51-58. http://dx.doi.org/10.1016/j.agee.2011.05.029

[29] Phillips, V.R., Lee, D.S., Scholtens, R., Garland, J.A. and Sneath, R.W. (2001) SE-Structures and Environment: A Review of Methods for Measuring Emission Rates of Ammonia from Livestock Buildings and Slurry or Manure Stores, Part 2: Monitoring Flux Rates, Concentrations and Airflow Rates. Journal of Agricultural Engineering Research, 78, 1-14. http://dx.doi.org/10.1006/jaer.2000.0618

[30] Scholtens, R., Wagemans, M.J.M. and Phillips, V.R. (2003) Improved Passive Flux Samplers for Measuring Ammonia Emissions from Animal Houses, Part 2: Performance of Different Types of Sampler as a Function of Angle of Incidence of Airflow. Biosystems Engineering, 85, 227-237. http://dx.doi.org/10.1016/S1537-5110(03)00016-3

[31] Sneath, R.W., Beline, F., Hilhorst, M.A. and Peu, P. (2006) Monitoring GHG from Manure Stores on Organic and Conventional Dairy Farms. Agriculture, Ecosystems \& Environment, 112, 122-128. http://dx.doi.org/10.1016/j.agee.2005.08.020

[32] Tingey, D.T., Waschmann, R.S., Phillips, D.L. and Olszyk, D.M. (2000) The Carbon Dioxide Leakage from Chambers Measured Using Sulfur Hexafluoride. Environmental and Experimental Botany, 43, 101-110. http://dx.doi.org/10.1016/S0098-8472(99)00051-9

[33] Zhang, Y. and Graakeer, W. (1998) An Inflatable Cover for a Concrete Manure Storage in a Swine Facility. Applied Engineering in Agriculture, 14, 557-561. http://dx.doi.org/10.13031/2013.19415

[34] Sommer, S.G., Zhang, G.Q., Bannink, A., Chadwick, D., Misselbrook, T., Harrison, R., Hutchings, N.J., Menzi, H., Monteny, G.J., Ni, J.Q., Oenema, O. and Webb, J. (2006) Algorithms Determining Ammonia Emission from Buildings Housing Cattle and Pigs and from Manure Stores. Advances in Agronomy, 89, 261-335. http://dx.doi.org/10.1016/s0065-2113(05)89006-6

[35] Osada, T., Rom, H.B. and Dahl, P. (1998) Continuous Measurement of Nitrous Oxide and Methane Emission in Pig Units by Infrared Photoacoustic Detection. Transactions of the American Society of Agricultural Engineers, 41, 11091114. http://dx.doi.org/10.13031/2013.17256

[36] Phillips, V.R., Sneath, R.W., Williams, A.G., Welch, S.K., Burgess, L.R., Demmers, T.G.M. and Lynn Short, J. (1997) Measuring Emissions Rates of Ammonia, Methane and Nitrous Oxide from Full-Sized Slurry and Manure Stores. Proceedings of the International Symposium: Ammonia and Odour Control from Animal Production Facilities, Vinkeloord, 6-10 October 1997, 197-208.

[37] Misselbrook, T.H., Brookman, S.K.E., Smith, K.A., Cumby, T., Williams, A.G. and McCrory, D.F. (2005) Crusting of Stored Dairy Slurry to Abate Ammonia Emissions: Pilot-Scale Studies. Journal of Environmental Quality, 34, 411419.

[38] Sommer, S.G., Christensen, B.T., Nielson, N.E. and Schjørring, J.K. (1993) Ammonia Volatilization during Storage of Cattle and Pig Slurry: Effect of Surface Cover. The Journal of Agricultural Science, 121, 63-71. http://dx.doi.org/10.1017/S0021859600076802

[39] Hornig, G., Turk, M. and Wanka, U. (1999) Slurry Covers to Reduce Ammonia Emission and Odour Nuisance. Journal of Agricultural Engineering Research, 73, 151-157. http://dx.doi.org/10.1006/jaer.1998.0402 
[40] Barrington, S.F. and Moreno, R.G. (1995) Swine Manure Nitrogen Conservation in Storage Using Sphagnum Moss. Journal of Environmental Quality, 24, 603-607. http://dx.doi.org/10.2134/jeq1995.00472425002400040008x

[41] Peterson, J., Agnew, J., Laguë, C. and Gaudet, E. (2004) Greenhouse Gas Emissions from a NAP-Covered Earthen Manure Storage Basin. North Central ASAE/CSAE Conference, Annual Intersectional Meeting, 24-25 September 2004.

\section{Submit or recommend next manuscript to SCIRP and we will provide best service for you:}

Accepting pre-submission inquiries through Email, Facebook, Linkedin, Twitter, etc A wide selection of journals (inclusive of 9 subjects, more than 200 journals)

Providing a 24-hour high-quality service

User-friendly online submission system

Fair and swift peer-review system

Efficient typesetting and proofreading procedure

Display of the result of downloads and visits, as well as the number of cited articles

Maximum dissemination of your research work

Submit your manuscript at: http://papersubmission.scirp.org/ 